\title{
The Survey on Deployment of E-Resources in District Central Public Libraries in Andhra Pradesh: The User's Perspective
}

\author{
M. Srinivasa Rao \\ Department of Library and Information Science, Andhra University, India \\ V. Dhana Raju \\ Department of Library and Information Science, Andhra University, India
}

\begin{abstract}
The Future Public Libraries are filled with Electronic resources. All the public libraries in India need to improve the e-resource to meet the user information needs. Implementation of Information Communication Technology in the district central public libraries have to instruct their subordinate public libraries in the district., The utilization of the Internet, and conduction of the Digitization process in the district central public libraries in the state. The Community has to give their support to the implementation of information communication technologies and develop the electronic resource in the Central Coastal district public libraries in Andhra Pradesh. Sometime in the future, a public library is a room with a bookshelf and a computer terminal per person. The shelves are mostly bare of books and instead stuffed with old conventional documents. The Indian government had initiated to development of the public library system. Chadavadam makistam (We Love Reading) concept was initiated by the government of Andhra Pradesh, to improve the reading habitation in school level children.
\end{abstract}

Key Words: Public Libraries; Electronic resources; Information Communication Technology; Internet; Digitization; Community; Central Coastal; Andhra Pradesh.

\section{Introduction}

The Implementation of information communication technologies is not a big issue in today's district central public libraries in the country. The UNESCO had started to cooperate with the establishment of public libraries in all the member countries in the world that are both developing and developed countries. The UNESCO aimed that all the public libraries be established their own in their respected countries for that the UNESCO has funded. The public libraries are helped to inculcate ICT knowledge in the civilians. The library user's or clients' involvement plays a vital role to develop society. The library users' community have to repay their reading materials like books and rare materials. They can donate in the form of computers and their allied peripherals. ICT is acting as a bridge between local and global. Public library users had gained knowledge from many things through using information communication technologies in the district central public libraries. When the Implication of ICT in district central public libraries, the users can actively participate and acquire updated knowledge.

\section{Literature review}

Zakrajisek (2020). Described that Public libraries assume an essential part in giving data, schooling, and social exercises to neighbourhood populaces. The specialist based topographical demonstration is a technique for reproducing complex metropolitan conditions utilizing heuristic and approximate calculations. The specialist model for public libraries produced for this investigation shows the opportunities for examining openness, investigating segment information of possible clients, finding underserved territories, and looking for the best areas or movement destinations for libraries. This model has been carried out and tried utilizing the whole public library organization of Slovenia. Results recommend that specialist based topographical displaying is a promising strategy for research in the field of library and data science.

Kulkarni (et...al) (2017), explored that Smart libraries for smart cities: a historic opportunity for quality public libraries in India, public libraries are needed to operate with the private and public sector to enhance the quality service to the community. Also discussed in their study quoted that Indian prime minister delivered his message that urban development in Indian cities has the plan to develop 100 smart cities and also launched two important schemes namely "Smart Cities Mission", AMRUT ( Atal Mission for Rejuvenation and Urban Transformation" this project will come under 500 cities in India. Kulkarni et...al mentioned that present situation of Indian public libraries, some cities ( 8 million people) in India does not have a single library.

Khan (2016), portrayed that Impact of Library, Information and Communication Technology (ICT) on library and its administrations, Computing innovation, correspondence innovation, and mass stockpiling innovation are a portion of the territories of ceaseless advancement that reshape the 


\section{Yinternational Research Journa!}

p-ISSN 2202-2821 e-ISSN 1839-6518 (Australian ISSN Agency)

manner in which libraries access, recover, store, control, and scatter data to clients. ICT has affected each circle of scholastic library action, particularly as the library assortment advancement procedures, library building, and consortia. Information and Communication Technology (ICT) has carried phenomenal changes and changes to scholarly library and data administrations, traditional LIS like OPAC, client administrations, reference administration, bibliographic administrations, current mindfulness administrations, report conveyance, interlibrary credit, varying media administrations, and client relations can be given all the more productively and viably utilizing ICT, as they offer advantageous time, place, cost-adequacy, quicker and generally modern dispersal and end-clients engaged with the library and data administrations measure.

Ronkova (2015) analyzed that Public libraries assume a fundamental part in giving data, instruction, and social exercises to neighbourhood populaces Specialist based topographical demonstration is a technique for reenacting complex metropolitan conditions utilizing heuristic and approximated calculations. The specialist model for public libraries produced for this examination shows the opportunities for investigating openness, investigating segment information of possible clients, finding underserved zones, and looking for the best areas or migration locales for libraries. This model has been carried out and tried utilizing the whole open library organization of Slovenia. Results recommend that specialist based geological displaying is a promising technique for research in the field of library and data science.

Kaur and Walia (2015) portrayed the assortment improvement and the board in the public libraries administered by the public authority or its organizations in Delhi and contrast them and the worldwide guidelines for public libraries. It was discovered that with the coming of ICT and its effect on society, it is clear that the public libraries are not putting forth the ideal attempt to connect with general society and make it more interesting to the clients. The primary issue with the library stays to be the absence of enrollment. A couple of drives have been taken, yet, there were very few computerized administrations being given by these public libraries in the present-day advanced climate.

Gosh (2004), Depicted that challenges that presently facing public libraries in India are not permanent all the public libraries are needed to implement the ICT technologies, and also discussed the present situation of public libraries in Maharashtra state. Gosh suggested that necessary actions have been taken to transform the present situation in the public library system in Maharashtra state, latest ICT technologies in
Vol. 12 No. 012022

828012012022193 (C) Author(s)

public libraries that already change the importance of Information communication technologies in public libraries, if the government of India take any serious implementation ICT technologies in public libraries, open public access in public libraries providing some government policies are useful to the user community.

\section{E-Public Library Services:}

\section{A. Digitization}

Digitization is the process of bringing traditional sources into digital (Electronic) sources. Digitization is an important process in the Collection Development of the library. Public libraries engaged with their collection development digitization with the help of their neighbour libraries. Digital collection in public libraries, initiated to pool up the digital collection, started digitalization process in their public libraries, digital collections in Croatian public libraries are small. All the public libraries are supposed to enhance their number of digital collections in the future. (Vrana, 2009, Pp.12)

\section{B. Health Information Clubs (Chowdary,2003)}

During the Pandemic Covid-19, Public libraries played a vital role in India. Public libraries have to create awareness on social distance and appropriate sanitization in the community of the use. All the public libraries are closed of Public awareness on social distancing and personal hygiene COVID19 cases were distinguished, of which $15.7 \%$ happened in work environments, for example, medical care offices, call focuses, sports clubs, public libraries, and nightlife objections. When the first affirmed case was analysed, the Korean Centre for Disease Control and Central Disaster Management Base camp reacted rapidly, accentuating early identification with various tests and a social distancing strategy. (Kim, 2020).

\section{Clubs for Home Work}

Toronto Public library operates the "Leading to reading" Program. It helps students improve their reading and learning skills. Home Work Clubs is a program conducted by 33 public libraries in Toronto out of 99 public library centres. Library Staff Members recruit the volunteers and train them from the age group is High School age to Senior citizens in the country. (Education World, 2021)

\section{Developing Reading Habit in Children}

Reading habits can encourage not only books and journals but also Non-Book Materials like CDs, DVDs, E-Books, EJournals and so on. Using Emerging Technologies helps to enhance reading habits in the students. (Oriogu, 2015)This is an innovative activity in public libraries, according to the 


\section{Yinternational Research Jaurna!}

p-ISSN 2202-2821 e-ISSN 1839-6518 (Australian ISSN Agency)

survey on different places, girl student's higher interest than boy students in reading habits (Ronkova, 2015, Pp.12041208).Chadavadam makistam (We Love Reading) concept was initiated by the government of Andhra Pradesh, to improve the reading habitation in school level children.

\section{E. Facility Visit Public Library}

The location of a public library is very important to easy to visit, according to Dr. Sarvepalli stated that always library situated the heart of the town, city or metropolitan city so that the very frequent to visit the library for fulfilling user information needs. Public libraries always attract the users to visit the library, public libraries are following some nontraditional activities that is the location of the library. The geographical information system can help to find the public library where they are located so there is a need to tag the public libraries with a global positioning system (GPS). GPS provide the location information about the public library. Users always select nearby libraries to visit, and users did not think whether small libraries or large libraries that is why public library always available to convenience to the users' timing and location. (Zakrajisek,F.J., \& Vodeb, V. (2020).

\section{Analysis and Data interpretation}

\section{A. Demographic Information}

The demographic examination provides different kinds of factors. It is relegated to socio, economic information articulated statically. Andhra Pradesh consists of 13 districts. The questionnaire was distributed among the users in two different groups' i.e. male and female. Data were collected from the district central libraries in the central coastal districts of Andhra Pradesh as a pilot study of users, awareness and utilization of ICT Technologies in public libraries.

\section{Table1. Gender Information Vs District wise distribution}

The following table represented gender-wise information of the respondents; results are also gender-wise distribution of the sample.

\begin{tabular}{|c|c|c|c|c|}
\hline \multirow{2}{*}{ Gender } & Krishna & $\begin{array}{c}\text { West } \\
\text { Godavari }\end{array}$ & $\begin{array}{c}\text { East } \\
\text { Godavari }\end{array}$ & Total \\
\cline { 2 - 5 } & $(\mathbf{N = 9 3 )}$ & $(\mathbf{N}=\mathbf{8 7})$ & $\mathbf{( N = 9 1 )}$ & $(\mathbf{N = 2 7 1 )}$ \\
\hline \multirow{2}{*}{ Male } & 69 & 58 & 78 & 205 \\
& $(25.46)$ & $(21.4)$ & $(28.78)$ & $(75.65)$ \\
\hline \multirow{2}{*}{ Female } & 24 & 29 & 13 & 66 \\
& $(8.86)$ & $(10.7)$ & $(4.8)$ & $(24.35)$ \\
\hline \multirow{2}{*}{ Total } & 93 & 87 & 91 & 271 \\
& $(34.32)$ & $(32.1)$ & $(33.58)$ & $(100)$ \\
\hline
\end{tabular}

The above table depicted the Gender wise information in the central coastal districts of Andhra Pradesh, The Highest respondents of the male category responded that awareness of
Vol. 12 No. 012022 828012012022193 (C) Author(s)

information communication technology, from East Godavari district central library with $28.78 \%$, followed by Krishna district central library with $25.46 \%$, and the lowest male respondents are from West Godavari district central library with $21.4 \%$. According to Female respondents who are aware of information communication technology, the highest respondents are from West Godavari District Central library with $10.7 \%$, followed by Krishna district central library with $8.86 \%$, and the lowest female respondents are from East Godavari district central libraries with $4.8 \%$. Male represents Dark Blue, Female represents Green in colours.

Fig. 1. Gender information

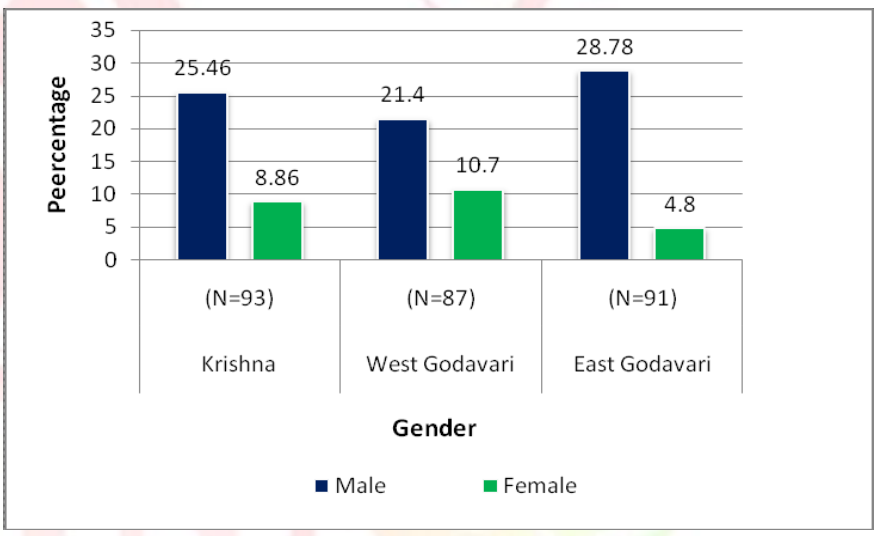

B. Information on Age vs. District wise distribution

This table represents the respondent who is participating in the survey in the central coastal districts of Andhra Pradesh. The researcher had segregated the users into five groups.

\begin{tabular}{|c|c|c|c|c|}
\hline \multirow{2}{*}{ Age } & Krishna & $\begin{array}{c}\text { West } \\
\text { Godava } \\
\text { ri }\end{array}$ & $\begin{array}{c}\text { East } \\
\text { Godavari }\end{array}$ & Total \\
\cline { 2 - 5 } & $(\mathbf{N = 9 3 )}$ & $\mathbf{( N = 8 7 )}$ & $(\mathbf{N = 9 1 )}$ & $(\mathbf{N = 2 7 1 )}$ \\
\hline Below 15 Years & $\begin{array}{c}15 \\
(5.54)\end{array}$ & $\begin{array}{c}17 \\
(6.27)\end{array}$ & $\begin{array}{c}12 \\
(4.43)\end{array}$ & $\begin{array}{c}44 \\
(16.24)\end{array}$ \\
\hline 16 to 25 Years & 24 & 26 & 19 & 69 \\
& $(8.86)$ & $(9.59)$ & $(7.01)$ & $(25.46)$ \\
\hline 26 to 35 Years & $\begin{array}{c}26 \\
(9.59)\end{array}$ & $\begin{array}{c}22 \\
(8.12)\end{array}$ & $\begin{array}{c}29 \\
(10.7)\end{array}$ & $\begin{array}{c}77 \\
(28.41)\end{array}$ \\
\hline 36 to 50 Years & $\begin{array}{c}18 \\
(6.64)\end{array}$ & $\begin{array}{c}13 \\
(4.8)\end{array}$ & $\begin{array}{c}17 \\
(6.27)\end{array}$ & $\begin{array}{c}48 \\
(17.71)\end{array}$ \\
\hline Above 50 Years & 10 & 9 & 14 & 33 \\
$(3.69)$ & $(3.32)$ & $(5.17)$ & $(12.18)$ \\
\hline Total & 93 & 87 & 91 & 271 \\
& $(34.32)$ & $(32.10)$ & $(33.58)$ & $(100)$ \\
\hline
\end{tabular}

(Figures in Parentheses indicate percentage)

The above table described that age group of the respondents or user community to utilize the library service, awareness on the information communication technology in the central coastal districts of Andhra Pradesh, represents the different levels of age groups who were selected from the universe The highest percentage of them $(28.41 \%)$ belongs to between age groups 


\section{Sinternational Research Journal}

p-ISSN 2202-2821 e-ISSN 1839-6518 (Australian ISSN Agency)

of 26-35years, The second largest of age group is (25.46\%) are from the age group between the 16-25 years, the thirdhighest of the age group of 36-50 years, below 15 years are from 16.24 , above 50 years age group is 12.18 representing respectively.

Fig.2: Information on Respondents Age

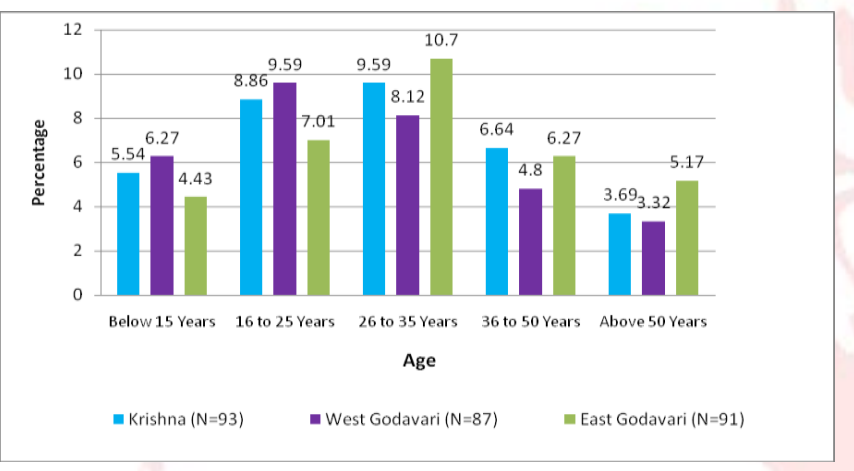

\section{Educational Qualifications}

This table represents the educational qualifications of the respondents. the researcher has segregated into five groups from the elementary school to $\mathrm{PhD}$ holders in the central coastal districts of Andhra Pradesh.

\begin{tabular}{|c|c|c|c|c|}
\hline $\begin{array}{c}\text { Education } \\
\text { Qualification }\end{array}$ & Krishna & $\begin{array}{c}\text { West } \\
\text { Godavari }\end{array}$ & $\begin{array}{c}\text { East } \\
\text { Godavari }\end{array}$ & Total \\
\cline { 2 - 5 } & $(\mathbf{N = 9 3 )}$ & $\mathbf{( N = 8 7 )}$ & $(\mathbf{N = 9 1 )}$ & (N=271) \\
\hline Below 10th Class & $\begin{array}{c}12 \\
(4.43)\end{array}$ & $\begin{array}{c}13 \\
(4.8)\end{array}$ & $\begin{array}{c}17 \\
(6.27)\end{array}$ & $\begin{array}{c}42 \\
(15.5)\end{array}$ \\
\hline $\begin{array}{c}\text { Intermediate / } \\
\text { Diploma }\end{array}$ & $\begin{array}{c}22 \\
(8.12)\end{array}$ & $\begin{array}{c}19 \\
(7.01)\end{array}$ & $\begin{array}{c}17 \\
(6.27)\end{array}$ & $\begin{array}{c}58 \\
(21.4)\end{array}$ \\
\hline $\begin{array}{c}\text { B Tech/B.A. /B. } \\
\text { Sc/B.Com. }\end{array}$ & $\begin{array}{c}33 \\
(12.18)\end{array}$ & $\begin{array}{c}37 \\
(13.65)\end{array}$ & $\begin{array}{c}39 \\
(14.39)\end{array}$ & $\begin{array}{c}109 \\
(40.22)\end{array}$ \\
\hline $\begin{array}{c}\text { M. Tech/M.A/M. } \\
\text { Sc/M.Com }\end{array}$ & $\begin{array}{c}22 \\
(8.12)\end{array}$ & $\begin{array}{c}15 \\
(5.54)\end{array}$ & $\begin{array}{c}13 \\
(4.8)\end{array}$ & $\begin{array}{c}50 \\
(18.45)\end{array}$ \\
\hline PhD/ Others & $\begin{array}{c}4 \\
(1.48)\end{array}$ & $\begin{array}{c}3 \\
(1.11)\end{array}$ & $\begin{array}{c}5 \\
(1.85)\end{array}$ & $\begin{array}{c}12 \\
(4.43)\end{array}$ \\
\hline Total & $\begin{array}{c}93 \\
(34.32)\end{array}$ & $(32.11)$ & $\begin{array}{c}91 \\
(33.58)\end{array}$ & $\begin{array}{c}271 \\
(100)\end{array}$ \\
\hline
\end{tabular}

(Figures in Parentheses indicate percentage)

The above table disclosed the Educational qualification among the respondents in the central coastal district of public libraries, the highest respondent's educational qualification is from B Tech/B.A. /B. Sc/B.Com with $40.22 \%$, followed by Intermediate / Diploma holders with $21.4 \%$ and the Lowest respondent's educational qualification is $\mathrm{Ph} . \mathrm{D}$. holders with $4.43 \%$, and reaming respondents qualification are $\mathrm{M}$. Tech/M.A/M. Sc/M.Com with $18.45 \%$, below 10 th class with $15.5 \%$ respectively.
Fig.3: Educational Qualifications

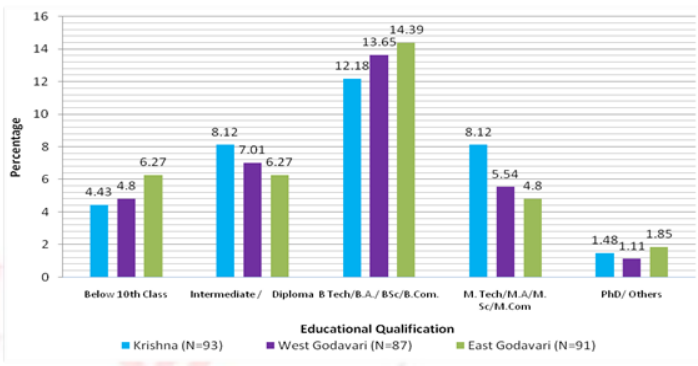

\section{Occupation}

The following table was described the professional and occupational groups of the respondents and their occupations are from students in primary education level to housewives and others.

\begin{tabular}{|c|c|c|c|c|}
\hline \multirow{2}{*}{ Occupation } & Krishna & West Godavari & East Godavari & Total \\
\cline { 2 - 5 } & $\mathbf{( N = 9 3 )}$ & $\mathbf{( N = 8 7 )}$ & $\mathbf{( N = 9 1 )}$ & $\mathbf{( N = 2 7 1 )}$ \\
\hline \multirow{2}{*}{ Student } & 9 & 11 & 17 & 37 \\
& $(3.32)$ & $(4.06)$ & $(6.27)$ & $(13.65)$ \\
\hline \multirow{2}{*}{ Employee } & 12 & 14 & 22 & 48 \\
& $(4.43)$ & $(5.17)$ & $(8.12)$ & $(17.71)$ \\
\hline \multirow{2}{*}{ Un Employed } & 35 & 29 & 38 & 102 \\
& $(12.92)$ & $(10.7)$ & $(14.02)$ & $(37.64)$ \\
\hline \multirow{2}{*}{ Business } & 9 & 8 & 5 & 22 \\
& $(3.32)$ & $(2.95)$ & $(1.85)$ & $(8.12)$ \\
\hline \multirow{2}{*}{ Farmer } & 8 & 7 & 4 & 19 \\
& $(2.95)$ & $(2.58)$ & $(1.48)$ & $(7.01)$ \\
\hline \multirow{2}{*}{ House Wife } & 4 & 4 & 2 & 10 \\
& $(1.48)$ & $(1.48)$ & $(0.74)$ & $(3.69)$ \\
\hline \multirow{2}{*}{ Others } & 16 & 14 & 3 & 33 \\
& $(5.9)$ & $(5.17)$ & $(1.11)$ & $(12.18)$ \\
\hline \multirow{2}{*}{ Total } & 93 & 87 & 91 & 271 \\
& $(34.32)$ & $(32.11)$ & $(33.59)$ & $(100)$ \\
\hline
\end{tabular}

(Figures in Parentheses indicate percentage)

The above table disclosed that respondents are from different professions and occupation aspects in the district central libraries in central coastal districts of Andhra Pradesh, highest respondent occupation of unemployed youth are utilizing the library facility in the central coastal districts of Andhra Pradesh with nearly $38 \%$ (37.64), followed occupation respondents are from Employees nearby 18\% (17.71), the lowest respondents occupation is Housewives nearby $4 \%$ (3.69) remaining are students are $13.65 \%$, other occupation groups are with $12.18 \%$, business respondents are from $8.12 \%$, Framers are also responding with $7.01 \%$ respectively.

Fig.4: Information about Occupation

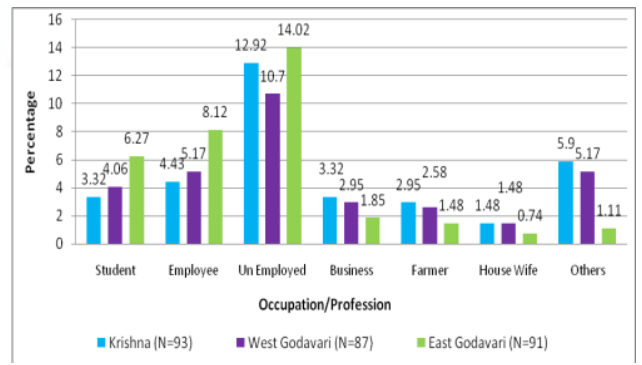




\section{E. User's opinion on Purpose of visit to the DCPLs}

The following table analyses the respondents who are coming to the library for what purpose. The researcher had prepared a questionnaire based on the services provided by the district central public libraries in the central coastal districts in Andhra Pradesh.

Table 5: User's opinion on Purpose of visit to the DCPLs

\begin{tabular}{|c|c|c|c|c|}
\hline Purpose of Visit & Krishna & $\begin{array}{c}\text { West } \\
\text { Godavari }\end{array}$ & $\begin{array}{c}\text { East } \\
\text { Godavari }\end{array}$ & Total \\
\cline { 2 - 5 } & $\mathbf{( N = 9 3 )}$ & $\mathbf{( N = 8 7 )}$ & $\mathbf{( N = 9 1 )}$ & (N=271) \\
\hline $\begin{array}{c}\text { To read Newspapers } \\
\text { and magazines }\end{array}$ & $\begin{array}{c}25 \\
(9.23)\end{array}$ & $\begin{array}{c}24 \\
(8.86)\end{array}$ & $\begin{array}{c}27 \\
(9.96)\end{array}$ & $\begin{array}{c}76 \\
(28.04)\end{array}$ \\
\hline $\begin{array}{c}\text { To borrow and return } \\
\text { the books }\end{array}$ & $\begin{array}{c}19 \\
(7.01)\end{array}$ & $\begin{array}{c}18 \\
(6.64)\end{array}$ & $\begin{array}{c}14 \\
(5.17)\end{array}$ & $\begin{array}{c}51 \\
(18.82)\end{array}$ \\
\hline $\begin{array}{c}\text { To prepare for } \\
\text { competitive } \\
\text { examinations }\end{array}$ & 27 & 30 & 34 & 91 \\
$(9.96)$ & $(11.07)$ & $(12.55)$ & $(33.58)$ \\
\hline $\begin{array}{c}\text { To improve general } \\
\text { knowledge }\end{array}$ & 13 & 10 & 9 & 32 \\
\hline $\begin{array}{c}\text { To read reference } \\
\text { materials }\end{array}$ & $(3.3)$ & $(3.69)$ & $(3.32)$ & $(11.81)$ \\
\hline Total & 93 & $\begin{array}{c}5 \\
(1.85)\end{array}$ & $(2.58)$ & $(7.75)$ \\
\hline$(34.32)$ & $(32.1)$ & $(33.58)$ & $(100)$ \\
\hline
\end{tabular}

(Figures in Parentheses indicate percentage)

The above table analyzed that the for what purpose of respondents are visiting the district central libraries in central coastal districts of Andhra Pradesh, The highest respondents are for to prepare competitive examinations with Nearly 34 $\%(33.58)$, followed by respondents are coming for to read newspapers with $28.04 \%$, the lowest respondents are coming for reading reference material with nearly $8 \% \quad(7.75)$ remaining respondents are for charging and discharging books and library material with 19\%(18.82), some respondents are coming for to improve general knowledge with 12\%(11.81) respectively.

Fig.5: Purpose of visit to the Library

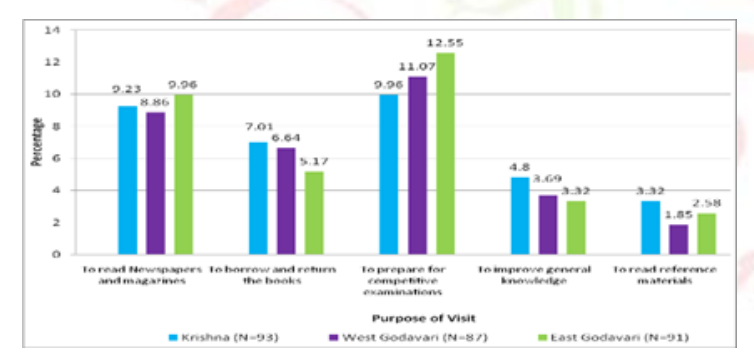

\section{F. Users opinion on Library Equipment in DCPLs}

The following table has described the user opinion on library equipment of the respondents in the district central public libraries in the central coastal districts of Andhra Pradesh. The library types of equipment that is computers, reprographic systems are very important to develop the electronic resources in the central public libraries.
Table 6. User's opinion on Library Equipment in DCPLs

\begin{tabular}{|c|c|c|c|c|}
\hline $\begin{array}{c}\text { Library } \\
\text { Equipment }\end{array}$ & Krishna & $\begin{array}{c}\text { West } \\
\text { Godavari }\end{array}$ & $\begin{array}{c}\text { East } \\
\text { Godavari }\end{array}$ & Total \\
\cline { 2 - 5 } & $(\mathbf{N = 9 3 )}$ & $\mathbf{( N = 8 7 )}$ & $(\mathbf{N = 9 1 )}$ & (N=271) \\
\hline Computers & $\begin{array}{c}34 \\
(12.55)\end{array}$ & $\begin{array}{c}33 \\
(12.18)\end{array}$ & $\begin{array}{c}30 \\
(11.07)\end{array}$ & $\begin{array}{c}97 \\
(35.79)\end{array}$ \\
\hline Internet Facility & $\begin{array}{c}25 \\
(9.23)\end{array}$ & $\begin{array}{c}24 \\
(8.86)\end{array}$ & $\begin{array}{c}27 \\
(9.96)\end{array}$ & $\begin{array}{c}76 \\
(28.04)\end{array}$ \\
\hline $\begin{array}{c}\text { Printers \& Xerox } \\
\text { Machines }\end{array}$ & $\begin{array}{c}19 \\
(7.01)\end{array}$ & $\begin{array}{c}18 \\
(6.64)\end{array}$ & $\begin{array}{c}17 \\
(6.27)\end{array}$ & $\begin{array}{c}54 \\
(19.92)\end{array}$ \\
\hline Closed Circuit & $\begin{array}{c}14 \\
\text { Cameras }\end{array}$ & $\begin{array}{c}12 \\
(5.17)\end{array}$ & $\begin{array}{c}15 \\
(4.43)\end{array}$ & $\begin{array}{c}41 \\
(5.54)\end{array}$ \\
\hline E-Resources & $\begin{array}{c}1 \\
(0.37)\end{array}$ & $\begin{array}{c}0 \\
(0.00)\end{array}$ & $(0.74)$ & $(1.11)$ \\
\hline Total & $\begin{array}{c}93 \\
(34.32)\end{array}$ & $\begin{array}{c}87 \\
(32.1)\end{array}$ & $\begin{array}{c}91 \\
(33.58)\end{array}$ & $\begin{array}{c}271 \\
(100)\end{array}$ \\
\hline
\end{tabular}

The above table described the library equipment in the central coastal districts of Andhra Pradesh. The highest respondents have an opinion on 'computers' are sufficiently available with a percent of 35.79 . followed by the' internet facility' with 28.04 percent. The least opinion on e-resource in the central coastal district of Andhra Pradesh is 1.11 percent of the respondents. The third and fourth opinion of places occupied by 'Printers and Xeroxography' (Reprographic facility) with $19.92 \%$ and CC Camera facility with 15.14 respectively.

Fig.6 Library Equipment

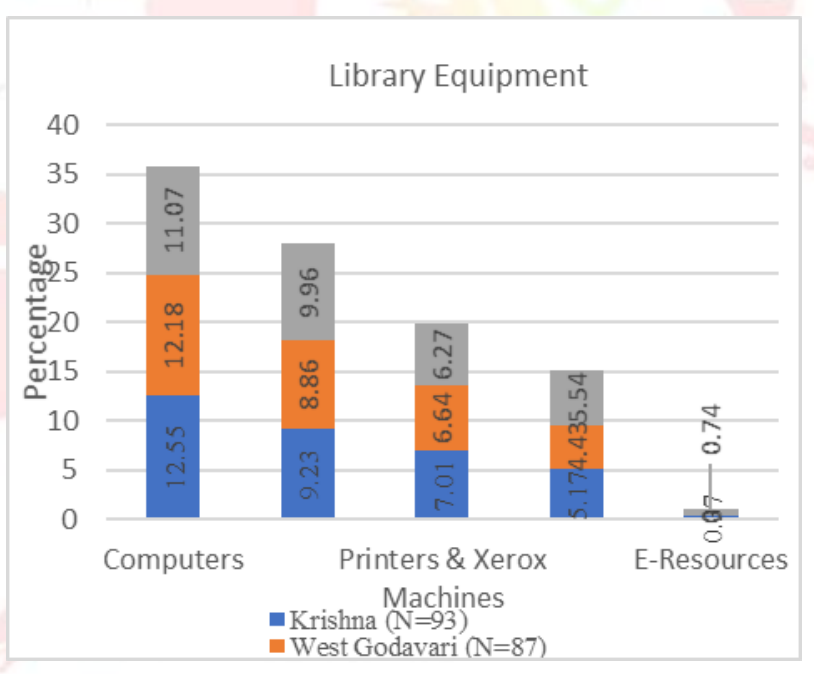

\section{G. Opinion on Overall services provided by DCPLs}

The researcher had to take an opinion on overall public library services in the central coastal districts of public libraries. The is completely based on their satisfaction level in all the services provided by the district central libraries. The researcher has taken 3 point scale to measure the user's satisfaction level which is Good, satisfied and poor. 
Table 7. Opinion on Overall services provided by DCPLs

\begin{tabular}{|c|c|c|c|c|}
\hline $\begin{array}{c}\text { Overall } \\
\text { Satisfaction }\end{array}$ & Krishna & $\begin{array}{c}\text { West } \\
\text { Godavari }\end{array}$ & $\begin{array}{c}\text { East } \\
\text { Godavari }\end{array}$ & Total \\
\cline { 2 - 5 } & $(\mathrm{N}=93)$ & $(\mathrm{N}=87)$ & $(\mathrm{N}=91)$ & $(\mathrm{N}=271)$ \\
\hline Good & $\begin{array}{c}43 \\
(15.87)\end{array}$ & $\begin{array}{c}39 \\
(14.39)\end{array}$ & $\begin{array}{c}49 \\
(18.08)\end{array}$ & $\begin{array}{c}131 \\
(48.34)\end{array}$ \\
\hline Satisfied & 36 & 29 & 27 & 92 \\
$(13.28)$ & $(10.7)$ & $(9.96)$ & $(33.95)$ \\
\hline Poor & 14 & 19 & 15 & 48 \\
$(17.7)$ & $(7.01)$ & $(5.54)$ & $271(100)$ \\
\hline Total & 93 & 87 & 91 & $(33.58)$ \\
\hline
\end{tabular}

The above table analysed the overall satisfaction levels of the users in the district central public libraries in the central coastal districts of Andhra Pradesh. The highest respondents are settled with 'Good' $48.34 \%$ of the district central public library facilities. The followed by 'Satisfied' with nearly 34 percent (33.95) of the users. The least per cent of the users are settled with 17.71 on account of 'poor'

Fig.7 Overall satisfaction on DCLs

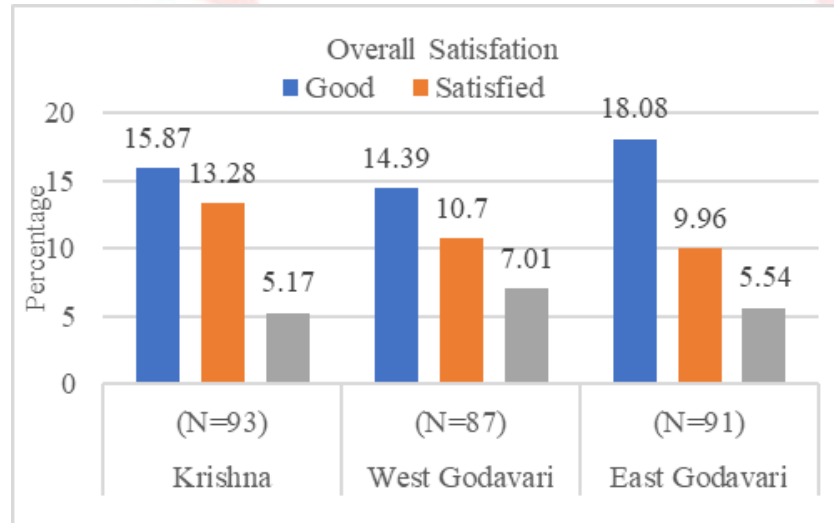

\section{Conclusion:}

A very low volume of e-resources is available in the district central libraries in the central coastal districts. Those eresources are CDs, DVDs some documents are available in open source. Public Libraries in Central Coastal Andhra Pradesh, India, need to digitise books, journals, and other print material to be made available electronically. There is a need to develop a website for the public libraries in Andhra Pradesh for sharing the latest resources with the neediest. Utilizing ICTs for the digitization process has been an important stepthe books are scanned and uploaded to a library's website. This has been possible because of a partnership agreement between the Central Coastal Districts. The people in the room are tapping away with their hands on the keyboard as most were wearing large gloves to protect their hands from repetitive motion injuries. A few people at the computers had translucent screens that they were typing on under the desk. The lighting was soft and people talking or tapping away on their keyboard can't be heard over the music that fills the room. There was a row of computers at one end of the room with almost all screens translucent for text editing

\section{References}

[1]. Campbell, H.C. (1982). Developing Public Library systems and Service, UNESCO, 92-3-104995-3, Paris.

[2]. Dr.Khan, Javed. (2016). Impact of Library and communication technology on library and its services, International Journal of Research Grandhralaya, Vo.14, No.9, Pp.2394-3629.

[3]. E.A. Kim (2020). Social Distancing and Public Health Guidelines at Work Place in Korea: Response to Corona Virus Desease-19, 275 283Pp.10.1016/j.shaw.2020.7006, safety and Health at Work.

[4]. Gosh, Maitrayee, (2004). Public Library System in India: Challenges and Opportunities, Library Review, Vo.53, No.3, Pp.180-191. DOI 10.1108/00242530510500935.

[5]. Kamble(et...al).(2016).Present Scenerio of Public libraries in India: Challenges and Opportunities.Journal of Academic research for Multidiciplinary,Vol.4(8),115-129. Issn.2320-5083.

[6]. Kaur,P.,\& Walia,P.K.(2015) - Collection Development and Management within Public libraries in Delhi, Library Management, 36(1/2), 99114. http://doi.org/10.1108/lm-11-2013-0104.

[7]. Kulkarni, S., \& Dhanamjaya, M. (2017). Smart libraries for smart cities: a historic opportunity for quality public libraries in India. Library $\mathrm{Hi}$ Tech News, 34(8), 26-30. https://doi.org/10.1108/lhtn-082017-0061.

[8]. Maitra, S. (1974). (9) The Public Library and Adult Education in India. International Library Review, 6(1), 55-60. https://doi.org/10.1016/00207837(74)90062-4.

[9]. National Library of India annual report, 27th Feb 2014.

[10]. Oriogu, Chuks Daniel. (2015). Catch Them Young: Developing and Improving of School Libraries and Reading Habit of Secondary School Students Nigeria, Journal of Education and E-Learning Research, Vol.2, No.4, Pp.60-63, 24109991.http://asianonlinejournals.com/index.php/JEEL R. 
[11]. Palmer, M. (2021). Study of Future Public Library Trends \& Best Practices. Public Library Quarterly, $1-25$.

https://doi.org/10.1080/01616846.2020.1868224.

[12]. Public Library Joint-use partnerships: Challenges and opportunities. (2014). Joint-Use Libraries, 2548. https://doi.org/10.4324/9781315864808-7.

[13]. Raju, K. A. (1997). Decentralised Development and the Role of Public Libraries in India. Public Library Quarterly, 16(1), 39-57. https://doi.org/10.1300/j118v16n01_05

[14]. Ronkova, J., Wildova,R (2015) . The Reading Matters: Children Readership in Czech Republic, Procedia - Social and Behavioral Sciences, 171, Pp.1204-

1208.https://doi.org/10.1016/j.sbspro.2015.01.232.

[15]. Sambasiva Rao, N., \& Nirmala Kumari, N. (2013). Revitalisation of Public Library System in India: A CSR Perspective. DESIDOC Journal of Library \& Information Technology, 33(1), 25-28. https://doi.org/10.14429/djlit.33.1.3726.

[16]. Toronto Public library (2021). Toronto Public library operates the "Leading to reading" Education World, https://www.educationworld.com.

[17]. Uraon, A., \& Sinha, M. K. (2019a). The National Library of India, Its Collection Development and ICT Based User Services: An Overview. Library Progress (International), 39(1), 125-133. https://doi.org/10.5958/2320-317x.2019.00013.8.

[18]. Vrana, Radovan(2010). Public libraries in Croatia and Digitization Challenge,Library Review, Vol.59, No.5 , Pp.325-340.0024-2535.

[19]. Yadav, S. K. (2021) "STUDY ON THE ESSENTIALS PARTS OF COOPERATIVE LEARNING", Amity Journal of Professional Practices. Florida, USA, 1(1). doi: 10.55054/ajpp.v1i1.460.

[20]. Zakrajisek,F.J., \& Vodeb, V.(2020). Agent-based Geographical Modeling of Public Library locations, Library and Information Science Research, 42(2), 10103.http://doi.org/10.1016/j.lisr.2020101013. 


\section{Manuscript Processing Footprints}

\section{A. Journal Volume/Issue Details}

This manuscript it published in Vol. 12 No. 012022 issue of IARS' International Research Journal (I'IRJ).

This is a Peer Reviewed (Refereed) International Journal published by IARS' Press Australia (International Association of Research Scholars) The Volume/Issue is a regular issue of the journal published in February 2022 Available at: https://researth.iars.info/index.php/curie.

\section{B. Copyright, License, and Publishing Rights}

- IARS' Press Australia (International Association of Research Scholars) respects the rights of the authors of research content published with IARS' International Research Journal. The "First Publication Rights" (FPR) to the original work accepted for publication at IARS' International Research Journal is granted to the Publisher of the Journal but copyright for all work published in the journal is retained by the author(s). Works published in the Journal is distributed under a Creative Commons Attribution 4.0 International License (CC BY 4.0). (This license lets others distribute, remix, adapt, and build upon your work, even commercially, as long as they credit you for the original creation. This is the most accommodating of licenses offered. Recommended for maximum dissemination and use of licensed materials.)

- After publishing the content with IARS' International Research Journal, the author holds complete right on the content for its amendments and reuse in any form. IARS' International Research Journal confirms that author(s) holds the copyright of the content.

- Author(s) grant(s) permission for their work to be indexed in part/full form in commercial and non-commercial indexes. Author(s) grant(s) permission for their work to be harvested in part/full form in commercial and non-commercial archives and distributed through them. Author(s) grant(s) permission for their work to be translated in part/full form in any language and republished and redistributed. Author(s) may enter into separate, additional contractual agreements for the non-exclusive distribution of the published version of the work, with an acknowledgement of its initial publication in this Journal.

- It is the responsibility of the author(s) to secure all necessary copyright and/or permissions for the use of third-party content in their manuscript(s). Author(s) have declared the same at the time of submission of manuscript and 'may also be required' to provide written evidence of this permission anytime in case required for any purposes.

- Publications Ethics and other Terms and Conditions as mentioned on official website of IARS' International Research Journal

\section{Last Plagiarism Report}

\section{SCREENED BY}

\section{$\checkmark$ iThenticate}

Settings: Quotes Excluded, Bibliography Excluded

\section{The Survey on Deployment of E Resources in District Central Public Libraries in Andhra Pradesh The user's perspective (1).docx \\ 1 part $-3,727$ words}

\section{Processing Track}

\begin{tabular}{|l|l|}
\hline Date of Submission & 03 February 2022 \\
\hline Date of Final Review & 25 February 2022 \\
\hline Date of Acceptance \& Schedule & 27 February 2022 \\
\hline Date of Publishing & 28 February 2022 \\
\hline
\end{tabular}

